\title{
LIMB MOVEMENT OF BASKETBALL ATHLETES IN SPORTS EXERCISE
}

\author{
MOVIMENTO DOS MEMBROS DE ATLETAS DE BASQUETEEM EXERCICIOS ESPORTIVOS
}

Original Article MOVIMIENTO DE LOS MIEMBROS DELOS ATLETAS DE BALONCESTO EN LOS EJERCICIOS FISICOS

Artigo OrIGINAL Artículo Original

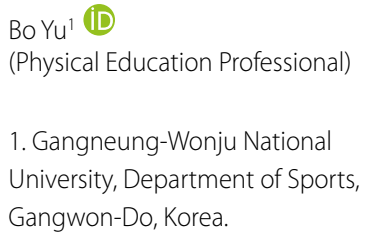

(Physical Education Professional)

1. Gangneung-Wonju National University, Department of Sports, Gangwon-Do, Korea.

\section{Correspondence:}

Bo Yu. Gangwon-Do, Korea. 25457. yb940722@163.com.

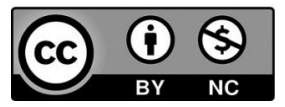

\begin{abstract}
Introduction: The performance of basketball players is based on physical function and quality. In addition to genetic factors, physical function can also be improved through acquired training. Objective: The article analyzes the concept of body movement through literature data and a questionnaire survey. Methods: This article analyzes the mechanical characteristics of basketball technology from the perspective of physiology and proposes methods to develop the strength of basketball players. Results: Through the activation of different training actions, controlling the muscles that maintain the stability of the limbs to adjust body balance is beneficial to improvement of the coordination and sensitivity of the muscles. Conclusion: Pay attention to the principle of incremental load, the SAID principle, and comprehensiveness in strength training. The training method adopted is helpful to the improvement of the athlete's aerobic metabolism. Level of evidence Il; Therapeutic studies - investigation of treatment results.

Keywords: Basketball; Athletes; Sports; Limbs.

RESUMO

Introdução: O desempenho dos jogadores de basquete é baseado na função física e na qualidade. Além de fatores genéticos, a função física também pode ser melhorada por meio de treinamento adquirido. Objetivo: O artigo analisa o conceito de movimento corporal por meio de dados da literatura e de um levantamento por questionário. Métodos: Este artigo analisa as características mecânicas da tecnologia do basquete a partir da perspectiva da fisiologia e propõe métodos para desenvolver a força em jogadores de basquete. Resultados: Por meio da ativação de diferentes ações de treinamento, o controle dos músculos que mantêm a estabilidade dos membros para ajustar o equilíbrio corporal é benéfico para melhorar a coordenação e a sensibilidade muscular. Conclusões: Constatamos que o princípio da carga incremental, o princípio SAID e a abrangência no treinamento de forçaéum método útil para aprimorar o metabolismo aeróbico do atleta. Nível de evidência ll; Estudos terapêuticos - investigação dos resultados do tratamento.
\end{abstract}

Descritores: Basquetebol; Atletas; Esportes; Membros.

\section{RESUMEN}

Introducción: El desempeño de los jugadores de baloncesto se basa en la función física y en la calidad. Además de los factores genéticos, también puede mejorarse la función física mediante el entrenamiento adquirido. Objetivo: El artículo analiza el concepto de movimiento corporal por medio de datos bibliográficos y de una encuesta por cuestionario. Métodos: Este artículo analiza las características mecánicas de la tecnología del baloncesto desde la perspectiva de la fisiología y propone métodos para desarrollar la fuerza en los jugadores de baloncesto. Resultados: Mediante la activación de diferentes acciones de entrenamiento, el control de los músculos que mantienen la estabilidad de los miembros para ajustar el equilibrio corporal es beneficioso para mejorar la coordinación y la sensibilidad muscular. Conclusiones: Hemos constatado que el principio de carga incremental, el principio SAID y la amplitud en el entrenamiento de fuerza es un método útil para mejorar el metabolismo aeróbico del atleta. Nivel de evidencia II; Estudios terapéuticos - investigación de los resultados del tratamiento.

Descriptores: Baloncesto; Atletas; Deportes; Miembros.

\section{INTRODUCTION}

Athletes' performance is based on physical function and quality, and their physical function can be improved through acquired training and genetic factors. At present, there are many relevant pieces of research and reports on the physical function changes of athletes before and after training. However, research on the physical function changes of young male athletes in adolescent development after training is still rare in China. ${ }^{1}$ This research is based on juvenile male basketball players who are in the growth and development period and whose physical fitness is in a sensitive development period. Observe the changes in grip strength, anaerobic power, maximum oxygen uptake, serum testosterone, immunoglobulin, and other indicators before and after one year of training. ${ }^{2}$ Analyze its athletic ability and physical function changes. We explore how to use scientific and reasonable training methods to improve their aerobic and anaerobic exercise capacity. This provides some help for better scientific training. 


\section{METHOD}

\section{Research objects}

There are 18 young male basketball players in competitive sports schools, with an average age of $14.5 \pm 1.5$. The average training year is $1.5 \pm 0.5$. Athletes are in good health, have no obesity, and have no history of heart, lung, liver, kidney, and endocrine diseases.

\section{Research methods}

We use the incremental load method to perform on the JAEGER treadmill. Perform once before and after training. The treadmill slope is $5^{\circ}$, the initial load is $9 \mathrm{~km} / \mathrm{h}$, and each level increases by $0.8 \mathrm{~km} / \mathrm{h}$. A load of each level lasts for $1 \mathrm{~min}$. We collected blood from athletes' ears at 2, 5, and 10 minutes after exercise. ${ }^{3}$ The blood lactic acid was measured with a YSI-23L lactic acid analyzer. Use PE-4000 telemetry heart rate monitor to measure heart rate. We use the Wingate method to do it on the MONARK-829 bicycle. Do it once before and after training. We asked the subjects to pedal at full force for the 30 s and tested the maximum and average power for 30s. The left and right-hand grip strength was measured once before and after training. Each subject was separated from venous blood before and after increasing load exercise. ${ }^{4}$ The serum is stored at $-20^{\circ} \mathrm{C}$. Ear blood was collected before exercise to measure hemoglobin. According to the test kit, serum testosterone, hemoglobin, immunoglobulins $\lg \mathrm{A}$, Ig M, and $\lg \mathrm{G}$ were determined. Use T-test for data processing. $P<0.05$ is the significance level, and $\mathrm{P}<0.01$ is the very significant level.

\section{Optimized simulation of a basketball player dunking upper and lower coordinated limb actions}

Based on the above-mentioned overall model construction and kinematic chain analysis, the movement parameter model analysis of dunk action in basketball is carried out. Analyze the explosive kinetic energy of the dunk action in the six-degree-of-freedom space. ${ }^{5}$ We first use the forward kinematics algorithm to obtain the joint angle space to obtain the force kinetic energy of the body function component in the dunk as

$$
K=\frac{1}{2} \sum_{i=0}^{6}\left[I_{i} \dot{q}_{i}^{2}+m_{i}\left(\dot{x}_{i}^{2}+\dot{z}_{i}^{2}\right)\right]
$$

Consider the upper limb mass $m_{3}$ as a center of mass. The analytical method is used to solve the inverse kinematics of multi-degree-of-freedom. ${ }^{6}$ The movement potential energy of basketball players after dunking is

$$
P=\sum_{i=0}^{6} m_{i} g z_{i}
$$

Under limited conditions, the equivalent pose equivalent motion chain structure of the continuous dunk action using the Lagrange dynamics model is

$$
\int_{V} \varepsilon_{i j} d V=\int_{V} \varepsilon_{i j}^{*} d V
$$

Obtain the energy equivalent relationship of basketball players in dunking action as

$$
\int_{V} \sigma_{i j} \varepsilon_{i j} d V=\int_{V}\left(\sigma_{i j}^{*} \varepsilon_{i j}^{*}\right) d V
$$

Under the macro conditions, the equivalent relationship of the stress of the two-dimensional periodic structure of a basketball player dunking is:

$$
\sigma_{i j}^{*} \varepsilon=\frac{1}{V} \int_{V} \sigma_{i j} d V
$$

Where $\sigma_{i j}$ represents the equivalent stress of the inverse kinematics of the right arm.

\section{RESULTS}

After a year of training, the height and weight of the juvenile male basketball players increased significantly $(P<0.01)$. The grip strength of the left and right hands also increased significantly $(P<0.01$, Table 1$)$. The peak anaerobic power and the mean value of anaerobic power, which are indicators of anaerobic capacity, did not change significantly $(P>0.05)$. The maximum oxygen uptake, the main indicator of aerobic capacity, increased significantly $(P<0.01$, Table 2). The blood lactic acid value of 2,5 , and 10 minutes after exercise was significantly reduced $(P<0.01$, Table 3$)$. There was no significant change in hemoglobin and serum testosterone ( $P>0.05$, Table 4). Immunoglobulins IgA, IgM, and IgG were significantly reduced $(P<0.01$, Table 5).

Table 1. Changes in height and weight of juvenile basketball players before and after training for one year $(\mathrm{N}=18)$.

\begin{tabular}{c|c|c}
\hline Index & Before training & After training \\
\hline Height $(\mathrm{cm})$ & $191.45 \pm 5.03$ & $193.10 \pm 5.14$ \\
\hline Weight $(\mathrm{kg})$ & $72.64 \pm 4.02$ & $75.64 \pm 5.41$ \\
\hline
\end{tabular}

Table 2. Changes in grip strength and anaerobic power of juvenile basketball players before and after one year of training $(\mathrm{N}=18)$.

\begin{tabular}{c|c|c}
\hline Index & Before training & After training \\
\hline Left-hand grip & $340.27 \pm 57.94$ & $367.27 \pm 43.44$ \\
\hline Right-hand grip & $347.27 \pm 56.41$ & $394.55 \pm 55.52$ \\
\hline Peak anaerobic work & $726.27 \pm 59.07$ & $704.10 \pm 75.64$ \\
\hline Mean anaerobic work & $571.60 \pm 74.92$ & $595.35 \pm 69.41$ \\
\hline
\end{tabular}

Table 3. Changes of maximum oxygen uptake before and after training and blood lactic acid after exercise for juvenile basketball players $(\mathrm{N}=18)$.

\begin{tabular}{c|c|c}
\hline Index & Before training & After training \\
\hline Maximal oxygen uptake & $4.15 \pm 0.44$ & $4.60 \pm 0.49$ \\
\hline Blood lactic acid 2min after exercise & $8.35 \pm 1.85$ & $5.32 \pm 2.93$ \\
\hline Blood lactic acid 5min after exercise & $9.11 \pm 2.57$ & $5.67 \pm 2.96$ \\
\hline Blood lactic acid 10min after exercise & $8.15 \pm 2.49$ & $4.99 \pm 2.31$ \\
\hline
\end{tabular}

Table 4. Changes of hemoglobin and serum testosterone of juvenile basketball players before and after one-year training ( $\mathrm{N}=18)$.

\begin{tabular}{c|c|c}
\hline Index & Before training & After training \\
\hline Hemoglobin & $15.17 \pm 0.66$ & $14.11 \pm 1.22$ \\
\hline Serum testosterone & $475.95 \pm 153.52$ & $450.99 \pm 128.83$ \\
\hline
\end{tabular}

Table 5. Changes of immunoglobulin before and after training for one-year juvenile basketball players $(\mathrm{N}=18)$.

\begin{tabular}{c|c|c}
\hline Index & Before training & After training \\
\hline $\lg A$ & $1.82 \pm 0.52$ & $1.31 \pm 0.23$ \\
\hline $\lg G$ & $10.95 \pm 1.69$ & $8.81 \pm 1.61$ \\
\hline $\lg \mathrm{M}$ & $1.67 \pm 0.60$ & $1.10 \pm 0.17$ \\
\hline
\end{tabular}




\section{DISCUSSION}

Height is a very important factor in basketball. The heritability of this indicator is high. The subjects in this experiment are basically in the puberty stage. 7 From the results, the height and weight increased significantly $(P<0.01)$, indicating that the experimental subjects have been trained for one year, which is in line with the law of growth and development of adolescents, and the training methods are reasonable. In terms of the natural growth law of strength quality, young people have a period of rapid growth, slow growth, and a period of stability. After 8-9 years of age, muscle development accelerates, and strength gradually increases. But after the age of 15 is a sensitive period for strong growth, especially the acceleration of the development of small muscle groups. ${ }^{8}$ Some data believe that the sensitive period of absolute power is 10-13 years old, and the sensitive period of relative power is 14-17 years old. The subjects of this experiment are entering this stage after increasing a certain percentage of strength training, and the grip strength of the left and right hands has increased significantly $(P<0.01)$. This shows that the strength exercises in training conform to the law of growth and development. However, in this study, it was found that the peak value of anaerobic work and the mean value of anaerobic work did not change significantly, which may be related to the increase in weight.

Basketball requires speed and endurance. In sports, jump shots, and other technical actions need to use ATP-CP and glycolysis for energy. ${ }^{9}$ This will produce a certain amount of lactic acid. In the competition, there are longer intervals to eliminate lactic acid through aerobic metabolism, so aerobic metabolism is beneficial to improving speed endurance. In this experiment, after one year of training load exercise, the lactic acid value decreased at 2, 5, and 10 minutes, and the maximum oxygen uptake increased significantly $(P<0.01)$. This reflects the improvement of aerobic metabolism. The use of a certain percentage of aerobic training among young athletes is of great benefit to improving basketball's specific level.

Hemoglobin and blood testosterone are closely related to exercise capacity and body function. A high hemoglobin value within a certain range means that the athlete has a stronger aerobic capacity and better physical function. ${ }^{10}$ In this experiment, the subjects' hemoglobin values and blood testosterone did not fluctuate significantly before and after one year of training. This shows that young male basketball players can adapt to this year's training.

Immunoglobulins (antibodies) are an important barrier against infection. Among them, lgG, IgM, and lgA have shown important effects on the immune function of the human body. $\lg G$ is the main component of serum immunoglobulin; most of the antibacterial and antiviral antibodies belong to lgG, which plays an important role in fighting infection. Secreted $\lg A(\lg A)$ is the main factor of the body's mucosal defense against infections, which can resist respiratory infections and digestive tract disorders caused by bacteria, fungi, and viruses. IgM plays an important role in preventing bacteremia.
In the past ten years, the relationship between immune function and exercise has attracted more and more attention. The academic circles believe that physical exercise can improve the body's immune parameters to prevent diseases. However, after strenuous exercise, heavy exercise training, and intense competition, athletes'immune function decreases and their susceptibility increases. Therefore, immunoglobulin can be regarded as an indicator of immune function and physical state. The level of serum immunoglobulin changes significantly when athletes are not adapted to heavy exercise. ${ }^{11}$ The combination of moderate exercise and reasonable nutrition can improve the level of immune function. It is generally believed that acute short-term moderate-intensity exercise activates the immune system and improves immune function. Long-term endurance exercise or long-term intensive training suppresses immune function. In high-intensity exercise, especially after exhausting exercise, the immune function of antibodies will be inhibited. Due to the decline in $\lg G, \lg A$, and $\lg M$, 8 of the 11 athletes caught colds, and most of them caught colds after the game. This shows that the immune function is affected, the immune function is reduced, and the ability to resist pathogenic microorganisms is weakened. Changes in immunoglobulin caused by exercise have a greater impact on the body. The mechanism is mainly due to the changes in the secretion levels of some hormones and nerve mediators such as opioid peptides, catecholamines, and corticosteroids in the body during exercise, thereby affecting and regulating the function of the immune system.

Children and adolescents have lower lgG and IgM than adults, which reflects poor disease resistance. In this experiment, the level of immunoglobulin of juvenile athletes decreased significantly. The analysis may be that the body repeats the next cycle of high-intensity training after a large amount of exercise training before its immune function has returned to normal. Such repetition leads to the so-called "Open window" period of deep suppression of immune function. This is a problem that needs to be paid attention to and solved in the training of young athletes.

\section{CONCLUSION}

After a year of training, the young male basketball players' height, weight, and grip strength have all increased significantly. This shows that training conforms to the law of growth and helps to improve the level of special events. After a year of training for young male basketball players, the blood lactic acid level decreased significantly, the ability to clear blood lactic acid was enhanced, and the maximum oxygen uptake was significantly increased. This shows that one year of training has significantly improved the aerobic metabolism of athletes. This experiment found that immunoglobulin decreased after one year of training. This is a problem that should be paid attention to in future training.

The author declare no potential conflict of interest related to this article

AUTHORS' CONTRIBUTIONS: Each author made significant individual contributions to this manuscript. Bo Yu: writing and article review.

\section{REFERENCES}

1. Vukasevic V, Mitrovic, M, Masanovic B. A comparative study of motor ability between elite basketball players from different regions. Sport Mont. 2020;18(1):3-7.

2. Ferioli $D$, Schelling $X$, Bosio A, La Torre $A$, Rucco $D$, Rampinini E. Match activities in basketball games: comparison between different competitive levels. J Strength Cond Res. 2020;34(1):172-82.

3. Vázquez-Guerrero J, Jones B, Fernández-Valdés B, Moras G, Reche X, Sampaio J. Physical demands of elite basketball during an official U18 international tournament. J Sports Sci. 2019;37(22):2530-7.

4. Arede J, Ferreira AP, Gonzalo-Skok O, Leite N. Maturational development as a key aspect in physiological performance and national-team selection in elite male basketball players. Int J Sports Physiol Perform. 2019;14(7):902-10.

5. Esteves PT, Mikolajec K, Schelling X, Sampaio J. Basketball performance is affected by the schedule congestion: NBA back-to-backs under the microscope. Eur J Sport Sci. 2021;21(1): 26-35.

6. Zhang S, Lorenzo A, Zhou C, Cui Y, Gonçalves B, Angel Gómez M. Performance profiles and opposition interaction during game-play in elite basketball: evidences from National Basketball Association. Int J Perform Anal Sport. 2019;19(1): 28-48.

7. Nabli MA, Ben Abdelkrim N, Fessi MS, DeLang MD, Moalla W, Chamari K. Sport science applied to basketball refereeing: A narrative review. Phys Sportsmed. 2019;47(4):365-74.

8. García-Santos D, Gómez-Ruano MA, Vaquera A, Ibáñez SJ. Systematic review of basketball referees' performances. Int J Perform Anal Sport. 2020;20(3):495-533.

9. Lemme NJ, Li NY, Kleiner JE, Tan S, DeFroda SF, Owens BD. Epidemiology and video analysis of Achilles tendon ruptures in the National Basketball Association. Am J Sports Med. 2019;47(10): 2360-6.

10. Pagé C, Bernier PM, Trempe M. Using video simulations and virtual reality to improve decision-making skills in basketball. J Sports Sci. 2019;37(21):2403-10.

11. Russell JL, McLean BD, Impellizzeri FM, StrackDS, Coutts AJ. Measuring physical demands in basketball: an explorative systematic review of practices. Sports Med. 2021;51(1):81-112. 